\title{
Belgeo
}

Revue belge de géographie

$4 \mid 2012$

Miscellaneous

\section{Learning for and from the city : the role of education in urban social cohesion}

Apprendre pour et de la ville : le rôle de l'apprentissage dans la cohésion sociale urbaine

Isabel André, André Carmo, Alexandre Abreu, Ana Estevens and Jorge Malheiros

\section{CpenEdition}

\section{Journals}

Electronic version

URL: http://journals.openedition.org/belgeo/8587

DOI: $10.4000 /$ belgeo.8587

ISSN: 2294-9135

Publisher:

National Committee of Geography of Belgium, Société Royale Belge de Géographie

\section{Electronic reference}

Isabel André, André Carmo, Alexandre Abreu, Ana Estevens and Jorge Malheiros, « Learning for and from the city : the role of education in urban social cohesion », Belgeo [Online], 4 | 2012, Online since 10 June 2013, connection on 10 December 2020. URL : http://journals.openedition.org/belgeo/8587 ; DOI : https://doi.org/10.4000/belgeo.8587

This text was automatically generated on 10 December 2020 .

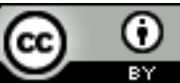

Belgeo est mis à disposition selon les termes de la licence Creative Commons Attribution 4.0 International. 


\title{
Learning for and from the city : the role of education in urban social cohesion
}

\author{
Apprendre pour et de la ville : le rôle de l'apprentissage dans la cohésion sociale
} urbaine

Isabel André, André Carmo, Alexandre Abreu, Ana Estevens and Jorge Malheiros

\section{Introduction}

Education and training consist of the practices and institutional configurations that involve the imparting, acquisition and construction of knowledge, i.e., structured information about the world, including facts, representations, meanings and values. Education is usually regarded as the broader concept of the two, in that it usually refers to the imparting and acquisition of any kind of knowledge (e.g. know-what, know-why), whereas training is typically used to refer to knowledge of an applied nature (know-how). Both are inextricably bound with the further concept of learning, which reflects an acknowledgement of the inherently active nature of the process whereby knowledge is produced. Depending on the theoretical perspective, learning and knowledge have been regarded either as the product of a one-sided social relation in the context of which the learner seeks to reproduce what is taught by the teacher, or as the result of an interactive relation whereby the learner constructs knowledge with the support of various educational agents (teachers, television, books, internet, etc.) and in various ways (observing, questioning, debating, etc.) (Glasersfeld, 1995 ; Wilson, 1996).

2 In everyday usage, the concepts of education and training hold a narrower sense, referring to the development of knowledge which meets somewhat more demanding, institutionally framed criteria: in particular, the criterion of taking place within institutions validated according to official scientific and pedagogical norms. This of 
course promotes the social recognition of certain types of education, learning and knowledge to the detriment of others, and in itself provides clear evidence of the sociopolitical character of the realities conveyed by these concepts. Indeed, learning and education are important constitutive elements of power relations, insofar as they can serve to advance and reinforce the extant economic, social and cultural structures including the dominant ideologies. At the same time, however, education and learning can also serve as a means to transform power relations through the dissemination and promotion of information, practices and values that do not conform to, and may even contradict or subvert, hegemonic knowledge (Bourdieu and Passeron, 1970).

Reflecting upon the role of education and learning in socio-spatial cohesion in the context of a holistic understanding of the latter, forces us to think beyond the mere "inclusive-liberal" mobilisation of education, which aims to tackle social exclusion by providing individuals with added skills that are recognised by the dominant institutions in society (particularly the labour market). It is true that, especially from the second half of the $20^{\text {th }}$ century, success in formal education has functioned as a crucial vehicle for social mobility. However, a holistic understanding of socio-spatial cohesion requires us to acknowledge, and explore more deeply, the fact that education and learning are also decisive in shaping society and its spatial forms in dynamic collective ways.

The review of 33 research projects in the education domain, funded by the European Union's Framework Programmes between 1994 and 2006 (André et al., 2009a), identifies four main types of research focused on the following sub-topics: i) education and training for the labour market; ii) institutional views on education and training; iii) creative and communicational learning; and iv) education, social inclusion and local development. The majority of the research is characterised by instrumental concerns with the economic consequences of learning and stresses the macro-scale. Just two research projects (Critical and Katarsis) focus specifically on the urban context, emphasising the social aspects of learning and the role of the local community. They explore the linkages between learning processes, exclusionary urban dynamics and socially creative strategies at the local level (Charles, 2007 ; Tierolf and Nederland, 2008). By and large, and not surprisingly in an era of "inclusive neoliberalism" (Porter and Craig 2004), the instrumental-individuation view of education and learning has predominated in recent research whereas the emancipatory-holistic view, supporting an (urban) context-sensitive educational approach is only rarely researched.

5 Assuming the later approach as a guideline, this paper argues that a research agenda focusing on the relationships between education/learning and socio-spatial cohesion, which can frame more progressive public policies, is both possible and desirable. It can be argued that the aforementioned relationship is not specific to urban contexts, as it involves both urban and non urban milieux. However, the responses of education towards the challenges to development and cohesion that are specifically explored in this article - innovation and creativity, citizenship, and cultural diversity - assume a particular and intense relevance in urban areas. Several authors, from Bairoch (1985) to Florida (2008), have stressed city features (more opportunities for cultural contact and exchange of ideas; higher levels of tolerance...) as particularly favourable to the emergence and initial diffusion of innovation. In addition, ethnic and cultural diversity are city markers, as already debated in Aristotle's Politics. This issue, relevant in Classical Athens, in the Ottoman Istanbul or in the Lisbon of the $16^{\text {th }}$ century Discoveries, continues to be crucial in the contemporary political and academic discourse. Sandercock (1998, p. 15) underlines, precisely, "the 
extraordinary cultural diversity" of "post-modern cities" and empirical data show that European metropolises are ethnically more diverse than nation-states (Malheiros, 2002). The challenges associated with the "neighbourhood issue", which involves questioning the marginalisation of some quarters, residential and school segregation or the limited social and labour market opportunities of immigrants" offspring (Kokoreff, 2003) and brings to the forae the collective bottom up processes that are being developed all over Europe (Moulaert et al., 2010), demonstrate how crucial these issues are in the contemporary urban milieux. Finally, if citizenship has been bounded, for more than two centuries, by nation-state features and by the specific "contract" between the "State" and its "people", recent changes in spatial order - the emergence of "network-space" and some subsidence of several territorial, state-like spaces as well as the reassertion of cities as political and social life organizers - are bringing "cityzenship" back to the "city".

\section{Education access and inequalities}

School attendance in developed countries is close to its theoretical maximum, i.e. almost $100 \%$ of children up to 14 years old and $82 \%$ of teenagers aged 15 to 19 attend school in OECD countries (OECD, 2009). This indicator has undergone impressive growth and between 1995 and 2007 increased from 74\% to 82\% (OECD 2009). This increase has been particularly pronounced in a number of Eastern and Southern European countries (Hungary, Czech Republic, Greece and Portugal), and constitutes a substantial improvement in terms of European territorial cohesion. This general picture of equality of opportunities conceals huge inequalities, mainly affecting those who did or do not have access to schooling, such as the older economically active population in Southern European countries or the immigrant population. In 2007, "the earnings premium for tertiary education is substantial in most countries and exceeds $50 \%$ in 17 out of 28 countries" (OECD, 2009, p. 137).

7 Also worthy of note is the impact of gender and ethnicity on educational performance (Crul, 2008). Data from the 2006 PISA Database (a cross-country profile of 15-year-old students) clearly shows the differences in school performance between native students and those with an immigrant background ${ }^{1}$, as well as gender differences that reproduce traditional patterns, such as men performing better in mathematics and science and women displaying better results in humanities.

8 The challenges posed by education and learning with regard to social cohesion are not limited to the gaps and differences pointed out above. On the one hand, scientific and technical knowledge evolves very quickly, causing the rapid obsolescence of the contents of the curricula adopted in schools and universities. On the other hand, the labour market (particularly its more highly skilled segments) requires constant learning and demands skills, such as autonomy and creativity, which traditional educational systems hardly provide. As a consequence, the improvement in the general levels of access to education does not curb social exclusion as effectively as in the past (Murie and Musterd, 2004).

The capacity of countries and cities to overcome these threats basically depends on the fulfilment of three conditions (Gradstein and Justman, 2002): investment in public education; the participation of communities in the design of educational programmes; and the development of a culture of schooling and learning among those social groups that largely ignore or reject the role of education in terms of empowerment potential. 
10 Another crucial threat that is closely related to the issue of urban cohesion concerns the profiling of schools. Generally speaking, it is clear that in the poorest quarters of many cities "black schools" tend to proliferate (Whitty, 2001) - "black" insofar as they face multiple problems of social exclusion risks and also because they tend to concentrate immigrant students. Most of these schools are locked in a vicious circle of disadvantage, the main issue often consisting of controlling and preventing violence, rather than developing innovative learning methods. Despite the supposed role of public schooling in compensating for social disadvantages and promoting social mobility, the effect of the family context remains very powerful. In addition, the local environment can either mitigate or strengthen these social disadvantages through the various effects that the places where people live exert upon their future social careers (Forrest and Kearns, 2001; Florida, 2008).

11 Moreover, the prevailing socio-political models decisively influence both the quality of public schooling and the most highly-valued skills accepted in a particular society. As an example, neoliberal orientations favour competition and summative assessment from an early age, to the detriment of critical thinking or teamwork strategies. At the university level these orientations are associated with the championing of individual entrepreneurism and the drive to disseminate ideas and approaches imported from a type of management and business administration usually dominated by concepts and grand discourses generated by the most important Anglo-Saxon business schools. By contrast, cooperation and participation are clearly undervalued. Behind the dominant logic lies the principle that competitiveness is the main development factor and the key for individual success, unjustifiably ignoring the fact that loss of cohesion undermines the functioning of society, leads to explicit conflict and violence, with youth and young adults as the major protagonists. Cities marked by contrast become a critical terrain for conflict, either in a violent or a constructive sense, the latter taking place when dissension is solved by negotiation, bridging gaps and compromise within a framework where social innovation emerges as a vehicle for social cohesion.

12 Within the context of what has been variously referred to as the age of information, information and communication technologies (ICT) - especially the Internet - have strong and controversial potential impacts on education and learning processes. On the one hand, the discussion has revolved around the possibility of regarding ICT as a set of instruments with potential to reduce inequity (e.g. by eliminating the costs associated with spatial distance via e-learning), and on the other as something which in itself is unable to transform significantly the underlying structural inequalities that characterize contemporary societies. Authors such as Sutton (1991) or Woolgar (2002), actually suggest that the use of ICT in different social contexts is more likely to contribute to the reproducing previously existent inequalities than to curb them.

13 From a critical perspective, Warschauer (2002) has suggested that the bipolar understanding of the digital divide (digital inclusion vs. marginalization from the digital realm - Norris, 2001; Graham, 2002) fails to recognize the fact that there is a dialectical relation between ICT and society. In terms of education and training, this means that without proper human and social resources (solid institutional arrangements, coherent educational strategies and models, etc.), the mere fact that learning environments provide physical devices and infrastructure does not necessarily lead to an enhancement of knowledge and skills development. 
14 As education and training frequently occur outside institutionalized formal contexts in tacit, unregulated and fluid ways, it is important to seek to understand the various impacts exerted by the ICT upon social relations. On the one hand, some have suggested that the internet provides a privileged arena for people to interact, form new social ties and relationships, and build virtual communities. On the other hand, its use is considered as something which promotes a sense of isolation and reduces face-to-face interpersonal contacts. A more nuanced understanding is that provided by Katz and Rice (2002), who suggest that both types of social relations influence each other, by promoting synergies both across media and between mediated and unmediated activities. Hence, the social use of the internet can promote positive interactions and social networking, as well as isolation and other socially harmful consequences. Still, at the local scale of the urban neighborhood, a number of experiences (e.g. Minnesota's e-Democracy initiative, Vivre le Marais! in Paris, the e-Re@l employability network in Lisbon, etc.) do seem to suggest that ICT can play an important role in many socio-urban processes by enhancing decentralization and delocalization while promoting local development, thus strengthening local communities through the aforementioned synergies with virtual communities.

\section{Education/learning and urban social cohesion : dealing with challenges}

15 Assuming the potentialities of education/learning for the reduction of inequalities and the promotion of inclusion and local community development, we now want to discuss how education systems deal with the three contemporary challenges to urban social cohesion that have been presented in the introduction: innovation and creativity, citizenship and interculturality. The key idea consists in discussing alternatives to more traditional perspectives of education - which promote "inclusive" innovation, creative thinking, citizenship with a "territorial consciousness" and an intercultural environment - and demonstrate how these foster development, urban social cohesion and local collective identities.

\section{Innovation and creativity}

16 The traditional view of education - based on numeracy and literacy capacities - has been confronted, especially in the early $20^{\text {th }}$ century, by alternative visions that have sought to shift the focus from the needs of the economic system to social development goals. Important social innovations inspired by these alternative visions, such as learnercentred education or the fostering of empowerment through the promotion of autonomous decision-making, have been introduced in some contexts - processes that have been characterised by Chambon et al. (1982) as "tiny revolutions" with a huge potential in terms of bringing about social change. The Freinet pedagogical methods in France, the "modern school" proposed by Francesc Ferrer in Catalonia and the practices inspired by the ideas of Paulo Freire in Brazil and Latin America constitute the main references in terms of educational alternatives and innovative experiences up to the 1970s (Freire, 1987). 
17 Another very important contribution is that of the American School of Pragmatism and, in particular, the ideas of Dewey (1997), a proponent of experiential education based on active learning and on the interrelationship between teacher and student. The school was regarded as the central institution of modern democratic societies, by "providing citizens with the skills and knowledge necessary for political participation" (Rury, 2002, p. 144), such as tolerance, fair-play, critical discussion of social issues and respect for the rights of others.

Incorporated in many pedagogical programmes since the 1970s, the theory of constructivism developed by Piaget may be considered as the single most important contribution to the promotion of creativity and innovation in the context of learning processes : learners are regarded as active agents who construct new knowledge from their own experiences.

In the 1960s and 1970s, these various perspectives on learning which ascribe an active role to the student and are actively committed to social change, found a particularly fertile ground in urban settings, where the possibilities in terms of individual freedom and equal opportunities are in general considerably greater.

The contemporary development of the knowledge-based society has led to some changes in educational and training requirements in order to comply with transformed competitiveness factors (Hoff et al., 2003; Furlanetto \& Oliveira, 2005). Therefore innovation and creativity have been positioned at the core of pedagogical aims, because the competitiveness of post-industrial economies requires people who can easily communicate, read and share information, work in teams and think creatively (Robinson, 2001). The rapid changes undergone by the labour market require flexible curricula based on transferable skills, which imply developing the students" capacity to deal with new problems and situations (Cropley, 2001). "Creative and cultural education are not subjects in the curriculum : they are general functions of education" (Robinson, 1999, p. 101).

21 Therefore, being creative and targeting innovation are requirements necessary both to competitiveness and social cohesion. Because contemporary competitiveness is nowadays bounded by the neoliberal principles of aggressiveness, low or non-regulated market action, generalised commodification and individualism, the bright side of (social) innovation is relegated to a second plan. Still, when enterprises are placed in their socially complex environments, typically urban, the promotion of social cohesion becomes an essential condition for reducing exclusion and violent social conflict, responsible for increasing negative externalities such as loss of working hours or the reduction of commitment and trust that lead to productivity decrease. In addition, enterprise competitiveness and urban competitiveness are closely connected, and highly divided cities portrayed as violent, unsafe and decaying become losers in the national and international urban hierarchies.

\section{Citizenship}

Citizenship has various meanings and several constitutive dimensions (Mouffe, 1992; Engin and Turner, 2002 ; Heater, 2004). Still, its complexity can be organised around two intertwined spheres of understanding: i) the relations between the members of a community and its spatial-political entity of reference; and ii) the relations of mutual support and solidarity that exist among such members because of a collective cultural identity and a shared sense of community. Whereas the former dimension is, to a certain 
extent, linked to the geographical notions of scale and place, the latter points to sociocultural relations established between individuals.

If we consider the arguments put forward by Kalberg (1993), it is possible to distinguish three periods in citizenship building, each with a particular socio-spatial configuration. Whereas in the pre-modern period, citizenship was associated with such socio-spatial units as the Greek "polis" or the medieval "bourg", the emergence of the nation-state is the defining feature of the modern period when citizenship became intrinsically related to the national scale. The post-modern period has witnessed the emergence of new sociospatial configurations and multi-scalar levels of citizenship. In the modern as well as post-modern periods, the school has played a crucial role in the (re)construction of citizenship by fostering the social and cultural integration of young people and the multiscalar networks of which they are a part.

As Mitchell (2003, p. 387) puts it, "the contemporary citizen of the twenty-first century is a member of a deterritorializing state". Actually, the modern nation-state has been waning while, at the same time, the regional and neighbourhood/local community (e.g. communitarian citizenship) scales, as well as the supra-national scale (e.g. cosmopolitan citizenship), have become more important (Santos, 2002 ; Davies, 2006; García, 2006; Osler and Starkey, 2003 ; Moulaert et al. 2010).

In order to tackle the challenges posed by these new socio-spatial configurations, education needs to stress the role of space and place - in other words, it has to take into account that the exercise of citizenship in 21st century society is strongly dependent upon what Klein and Laurin (2005, p. 240) have called "territorial conscience", that particular set of intellectual tools allowing individuals to identify the dialectic relations between local and global processes (e.g. economic, political, social, cultural, environmental) (González, 2007, p. 30). Hence, the urban space, which is regarded as a foremost arena in which these processes are lived, should also be seen as an appropriate environment for education processes to take place. It allows for an expansion of the possibilities found within the postmodern polis (i.e. public sphere), as it promotes interpersonal relations with the "other" while at the same time fostering personal reflexivity.

\section{Diversity and interculturality}

The issue of immigration in Europe has become the issue of post-migration. In fact, the trend for immigrant families to settle permanently in the "host" countries, alongside the changes in the demographic composition of immigrant populations (stronger presence of women, children and teenagers), have contributed significantly to centring the debates around the issue of the social integration of immigrant families (Castles and Miller, 1999). The permanent settling of immigrants is reflected in the increasing cultural diversity of European societies and has been challenging the old paradigms of uniformity and homogeneous cultural values. In addition, the growing number of young descendants of immigrants in the host societies poses specific challenges to the local institutions of those societies. All things considered, the permanent presence of immigrants and their offspring and the cultural diversification of European countries, especially their cities, have led to two major challenges: one related to the accommodation of cultural differences and the need to promote inter-cultural dialogue, the other to the process of 
the specific disadvantages experienced by immigrants and especially their offspring (e.g. language proficiency) in the destination societies (Rex, 1985).

The lack of formal cultural resources prevents immigrant parents and their children from fully mastering the educational codes used in the schools of the host societies (Crul, 2008; Batalha, 2004). In addition, the lack of economic resources often requires that parents work longer hours and prevents them from systematically monitoring their children's progress at school. Other authors also stress the role of ethnic issues such as the families" cultural background and specific co-ethnic social networks in this process (Lindo, 1995 ; Modood, 2003). In line with these insights, the concentration of immigrants" children in the aforementioned "black schools" located in urban neighbourhoods where immigrants cluster is also regarded as contributing to poorer school performances (Crul, 2008).

Most of the answers to these problems have been found within the principles of interculturality, e.g. the promotion of communication and positive interaction between the various cultural groups present in society. The development of the notion of interculturality has been more closely associated to the francophone world than to the anglo-saxon one, as demonstrated by the contributions of Clanet (1985) or Perroti (1994), and has been responsible for the emergence of a whole new line of thought in pedagogy, namely intercultural pedagogy. The institutionalisation of the notion of interculturality in the 1970s in France, or in the early 1990s in Spain and Portugal, took place within the framework of new education policies that sought to foster competences in the cultural diversity domain (Rocha-Trindade, 1993 ; Rafoni, 2003).

The practical implementation of these intercultural principles in schools has often taken the form of compensation policies that specifically target non-autochthonous children and seek to tackle their lack of linguistic and formal social competences. Specific courses on the host countries" language or the use of cultural mediators are two of the strategies that have been implemented in schools across several countries. In some, such as the Netherlands or Germany, the principles of multiculturalism and the belief in the likelihood of the eventual return of the immigrants" offspring to their parents" countries of origin framed a pedagogical line that stated the advantages of learning elements of the original language and culture of the immigrants" parents as part of school curricula ${ }^{2}$.

More recently, these multicultural perspectives have been strongly criticized as something that has limited the effective integration of the children and youth with nonautochthonous backgrounds into the host society, leading to fractures that challenge social cohesion, especially in urban milieux, where those groups are more concentrated. Therefore, since the mid-1990s, there has been a shift towards neo-assimilationist policies in a number of Central and Northern European countries, which comprehends such measures as compulsory integration courses for non-EU immigrants, including training in the host country's language and culture, or the incorporation of a more or less explicit notion of belonging to the imagined national community of the destination country (Waite, 2012).

31 All in all, the instrumental implementation of intercultural policies in schools has first and foremost sought to tackle the specific disadvantages faced by immigrants and their offspring, rather than aiming at the effective promotion of intercultural dialogue. Nevertheless, interesting experiences have been implemented in many EU countries and metropolises in such domains as the promotion of intercultural contacts in schools, conflict and cultural mediation, student exchange programmes between schools in the 
home and host countries, or the introduction of courses on the languages of origin countries that are part of the general school curricula and therefore open to every student. These initiatives involve old projects such as the Modéle du Foyer implemented in Brussels in the 1980s (Byram, 1991) or the Portuguese Intercultural Education Programme of the early 1990s as well as very recent ones, such as the initiative Povos, Culturas e Pontes (Peoples, Cultures and Bridges), presently being developed by the municipality of Seixal (Lisbon Metropolitan Area) with the purpose of strengthening the intercultural education strategies and offer and enabling contact - through the Internet or videoconference between pupils of local schools and pupils attending schools in the main places of origin of the immigrants.

\section{Links to urban policy : learning communities and the contribution of education to urban regeneration}

32 As we have previously argued, there has been insufficient debate on the articulation between learning as a means to achieve social cohesion and the city and/or urban neighbourhoods as active contexts for that process. Further theoretical discussion, methodological reflection and empirical analysis are required for a better understanding of the city both as a learning environment and as a learning resource - not least in order to be able to take this dimension into account effectively in the context of urban cohesion policies. The development of learning communities and the learning context that should support contemporary processes of urban regeneration are two examples of the triple link between learning, the city as a pro-active learning context and the strengthening of social cohesion.

\section{Local learning communities}

Learning communities, whether in their territorialised versions (learning cities, learning regions) or otherwise, are far from a novel concept. A bulging literature addressing the topic has flourished in recent years, typically as part of a broader trend revolving around the theory and ideology of the "knowledge-based economy" (Armstrong, 2001 ; David and Foray, 2002 ; Powell and Snellman, 2004). As might be expected, this latter approach to learning communities seeks to identify and mobilise the untapped potential of territories as regards the production and dissemination of knowledge with the main aim of enhancing economic competitiveness.

Yet, as argued by Lambooy and Moulaert (1996), it seems increasingly clear that "narrow, economistic notions of the learning city can only contribute to a growing polarisation of the city" (Plumb et al., 2007, p. 37) and do not challenge, but rather reinforce, the "overarching exploitative and wealth concentrating structure of the knowledge economy" (Plumb et al., 2007, p. 42). It is not that numerous relevant insights cannot be usefully mustered from the aforementioned theoretical perspectives - e.g., with respect to the heuristic and theoretical worth of the concepts of tacit and collective knowledge (Ferrão, 1995, 1996; Antonelli and Ferrão, 2001). But it is clear that in order for those insights to be successfully transposed to the analysis of the ways in which learning processes serve to reinforce or overcome exclusionary dynamics, it is necessary that social cohesion concerns take central stage, instead of playing second fiddle. 

the topic of learning communities should begin by explicitly opting for a definition of the latter that: i) is explicitly oriented towards "emancipatory learning", "really useful knowledge", "critical thinking" and "conscientisation" (Charles et al., 2007, p. 63) ; and ii) draws on the concept of "community of practice" as one where people learn creatively and collectively with a view to addressing problems and challenges that are themselves collective. In accordance with this perspective, learning has an irreducibly social and community character and it is closely related to the concept of empowerment (Friedman, 1992; Ninacs, 2008). Hence the strategic social cohesion potential of learning communities : through them, cohesion is promoted not only within the community itself, but also within the broader territory and society of which it is a part. This is particularly relevant in metropolises where social instability and spatial fragmentation strengthen the potential for exclusion and conflict as well as the loss of propinquity.

Research on the role and potential of learning communities as strategic drivers of social cohesion and community emancipation may usefully pursue a series of distinct but complementary paths. Among the main issues we would include: i) the "governmentality" - organised practices (mentalities, rationalities and techniques) through which subjects are governed - Mayhew, 2004) - of education in urban contexts ; ii) semiotic barriers to participation and empowerment, that is the insufficient mastery over signs, symbols and codes, by individuals and/or communities in contemporary cities; iii) the mechanisms that characterise the production and dissemination of "socially non-legitimised" knowledge by socially excluded groups and communities in urban milieux, often corresponding to vibrant and creative ways to addressing their specific problems and collectively devising solutions to them; and iv) good practices in "bridging" formal/institutionalised and informal/grassroots learning, particularly at the neighbourhood level.

The search for "good practices" in bridging formal/institutionalised and informal/ grassroots learning would seek to identify what it is that characterises those instances in which these two forms of learning engage in cross-fertilisation - on the one hand, through the incorporation of grassroots codes, practices and insights into formal curricula, with the aim of improving the richness, diversity and usefulness of the latter; on the other, through the active "reaching out" to excluded communities by formal education institutions as a way of empowering them.

The notion of "urban learning community" builds on the idea that "urban space (...) is not designed from on high (...;) rather, it is woven like cloth by [its] inhabitants as they engage with each other in acts of social learning in communities of practice" (Plumb et al., 2007, p. 46 , citing L. Brothers and J. Jacobs).

\section{Education and learning in the context of urban regeneration}

The democratisation of education and its multicultural profile in many European and North American cities has posed two relevant problems to the educational system. The first one concerns the role of schools as key local agents, mainly in the most problematic urban areas. In many cases, the school is the only access gate that is open to families to ask for various types of assistance. The second issue relates to the specific difficulty of reversing the exclusion of certain communities through the education of children and young people (Cummings and Dyson, 2007). In most cases, instead of improving the life 
patterns of local communities, schools contribute to reproducing the deprivation of the areas where they are located: degraded buildings, high levels of teacher mobility, crime and drugs inside the schools, etc.

The approach to these problems requires a redefinition of the roles played by schools in the context of their local communities, especially in the case of deprived urban areas. Over the last few decades, several European countries have developed local policies and strategies in order to deal with this issue. At first, these initiatives consisted mostly of special custom-made assistance to children and young people, with a view to improving their learning and school performance. Later on, the focus shifted to parental involvement and, more recently, to the involvement of the local community (Crowther $e t$ al., 2003).

41 The built environment is also relevant to enhance the role of schools as promoters of young people's self-esteem and social integration. Reflecting on the gap that exists between the educational systems of Northern and Southern Europe - which is partly responsible for the "brain drain" from the latter to the former, Moulaert et al. (2007, p. 144) highlight precisely this specific dimension of the phenomenon: "a problem of spatial planning and the built environment, including the lack of school buildings (which implies rotating classes and teaching times), the use of inappropriate buildings or vandalism affecting school infrastructure". Actually these conditions constrain the positive outcomes of the learning process, even when these are potentially stimulated by the aforementioned immaterial actions.

Nevertheless schools are often crucial agents of local development processes, not only through the bridges established between the school and the families but also as resource centres. The "Schools Plus" experience in the UK is a good example of this new role being assumed by schools, namely in terms of offering services to the community or simply providing the physical space for other agencies to locate inside school buildings (Crowther et al., 2003 ; Cummings and Dyson, 2007; Gordon 2008). More recently, the school has also emerged as a facilitator of connections with wider urban areas, seeking to break the isolation of dysfunctional enclaves and to expand the relational capital of children and young people.

These crucial roles of schools make them fundamental partners in several area-based regeneration processes that are taking place in several neighbourhoods of European cities where an over-representation of youth, and often of youth with an immigrant background, is found. For instance, the involvement of the local school and the creation of a Hip-hop Academy are critical actions in the integrated Programme Bairros Críticos (Critical Neighbourhoods) of the neighbourhood of Vale da Amoreira (southern periphery of Lisbon). Another example is provided by the role of schools in several initiatives (environment and local food production, solutions for obsolete infrastructure, stimulate entrepreneurialism) of the Kings Cross Central Regeneration process in London.

Also universities have emerged in the literature of the last few decades as important agents of urban regeneration, though in a different sense. For instance, some authors have stressed the role of universities within deprived local communities, namely referring to the possibility of them acting as "a bridge between regeneration professionals and the local community" (Robinson and Adams, 2008, p. 283).

The traditional campuses of Anglo-American Universities, whose model has been adopted in many other contexts across the world, has often been accused of giving rise to isolation 
and tensions vis-à-vis local neighbourhood communities (Bromley 2006). In order to engage universities in urban development strategies, two main alternatives have been put forward: (i) opening up the campuses not only to science and technology parks, but also to local micro-enterprises, third sector institutions, sports associations, local events, etc.; and ii) moving university buildings to the city centre in order to animate the commercial, cultural and other activities of that area, while at the same time promoting the requalification of the built environment (Perry and Wiewel 2005). Another strategy consists in locating Universities in peripheral urban areas that have been affected by negative processes of industrial relocation or concentrations of deprived housing, such as happened in the Southwest area of Madrid where partnerships involving municipalities, the Spanish Government, and the Regional government created the Charles III University of Madrid in 1989 and the King Juan Carlos University in 1996. Both universities have poles located in deprived metropolitan suburbs (Charles III University in Móstoles, Alcorcón and Fuenlabrada, and King Juan Carlos University in Leganés and Getafe). Nowadays these universities are well recognized in Europe and the municipalities could invert the decline trend attracting many other investments and skilled workers ${ }^{3}$. Similar cases are the settlement, in 1998, of the second University of Milano in the former industrial neighbourhood of Bicocca or the location of the School of Theatre and Cinema of the Portuguese National Conservatory in Amadora, a stigmatised municipality on the outskirts of Lisbon.

"To build excellence and invest in research-intensive universities and their graduate programs is to invest in the communities in which they are located. The university can act as a catalyst for economic development, but - more importantly - the university is also a crucial actor in making places more open and diverse, thereby contributing to wider goals of social inclusion and cohesion within Canadian society" (Gertler and Vinodrai, 2004, p. 10). An interesting European experience is the "migration" of two Faculties of the University of Barcelona from the Pedralbes Campus to the city centre the Raval neighbourhood - as anchors of the ongoing revitalisation process.

The desirable embeddedness of Universities in cities and their potential role in urban cohesion bring to light the need to find new partnership-based governance models. However, such profound changes in the status and functions of universities almost inevitably face strong adverse reactions on the part of the most conservative sectors of academia which support a monopoly of the "core businesses" of teaching and research.

\section{Conclusion}

The access to education has been tremendously expanded in developed countries. However, this "democratisation" of education has not been without its downsides - in particular, the greater risk of social exclusion where those affected by formal educational skills" deficits (such as the elderly, immigrants or specific national groups like the Roma) have found themselves; and the imposition of a rather homogeneous modernist educational model across all layers of often very heterogeneous populations. Other factors putting people and communities at risk of social exclusion are also closely linked to the issues of learning and education. For example, the quality of learning processes, which is influenced by prior endowments of cultural and social capital, is also strongly affected by certain specific features of schools (experience and motivation of the staff, adjustment of the courses to the needs of the students, pedagogical strategies adopted, 
material conditions) and has an impact in the performance of the students, contributing to a worsening of social and spatial divides. Certain city neighbourhoods and districts experience systematic disadvantages across a variety of educational aspects and, as a consequence, the schools located in those districts consistently exhibit below-average performance levels. Indeed, in many cases, schools actually contribute to segregation, rather than promoting social cohesion. The title of a book by Richard Florida (2008), "Who's your school ?" is certainly a good predictor of individual social mobility.

In recent times, the digital divide has become another important factor of social and spatial fragmentation. At the macro-scale, differential access to social and economic resources conditions the levels of access to ICT and thereby increases inequality. However, at the micro-scale, ICT (and the internet in particular) have also made it possible for many interesting learning processes and experiences to occur outside their traditional institutional contexts, have promoted the strengthening of community ties especially among such geographically-separated groups as migrants - and have encouraged empowerment strategies.

Despite the social and cultural inequalities that beset this social domain, education remains one of the main pathways to promoting social and urban cohesion, particularly via the development of competences related to creativity, citizenship and interculturality. Some requirements of the knowledge-based society and especially the "cultural turn" have brought creativity, innovation, critical thinking and artistic abilities to the centre of the learning and education debate (André et al., 2009b). The multi-scalar nature of contemporary territorial belonging and identity has posed some fundamental challenges to the theory and practice of citizenship as shaped by the modern nation-state of the $19^{\text {th }}$ and early $20^{\text {th }}$ century. Education for citizenship seeks to meet these challenges by linking the values and practices of tolerance, dialogue and sharing, while once again highlighting the city as a key locus of citizenship, where social and cultural interaction is compatible with individual freedom and privacy.

51 Finally, in urban contexts characterised by significant and increasing cultural diversity, intercultural dialogue has itself become an increasingly crucial issue. Intercultural interaction requires conflict mediation as well as organised learning processes that strengthen the links between human groups, foster the development of shared communication channels and contribute to assuming differences as a feature of everyday life requiring negotiation in order to prevent the transformation of difference into inequality.

This article has suggested two strategies linking education processes with social cohesion that can inspire future urban policies. The first concerns local learning communities based on the concept of communities of practice, focuses on the neighbourhood as a learning platform for and in the city and encourages cross-fertilisation - both between formal/institutional methods and grassroots practices, and between codified and tacit knowledge. The second strategy highlights the role of educational institutions as proactive agents of urban regeneration processes with a view to the construction of more socially creative cities, by emphasising their embeddedness in the urban community and calling for their active involvement in governance mechanisms and reconstructed areabased project partnerships. 


\section{BIBLIOGRAPHY}

ANDRÉ I., MALHEIROS J., ABREU A., \& CARMO A. (2009a), Education and Training (Social Polis) - Final Report, Lisbon, Centro de Estudos Geográficos.

ANDRÉ I., BRITO HENRIQUES H. \& MALHEIROS J. (2009b), “Inclusive Places, Arts and Socially Creative Milieux", in D. MACALLUM D., MOULAERT F., HILLIER J. \& HADDOCK S.V. (Eds.), Social Innovation and Territorial Development, London, Ashgate, pp. 217-241.

ANTONELLI C. \& FERRO J. (2001), Comunicação, Conhecimento Colectivo e Inovação : As Vantagens da Aglomeração Geográfica, Lisbon, Imprensa de Ciências Sociais.

ARMSTRONG P. (2001), "Science, enterprise and profit : ideology in the knowledge-driven economy", Economy and Society, 30, 4, pp. 524-552.

BAIROCH P. (1985), De Jericho à Mexico : villes et économie dans l'histoire, Paris, Gallimard.

BATALHA L. (2004), “Contra a corrente dominante : histórias de sucesso entre cabo-verdianos da segunda geração”, Etnográfica, VIII, 2, pp. 297-333.

BOURDIEU P. \& PASSERON J-C. (1970), La Reproduction. Éléments d'une théorie du système d'enseignement, Paris, Editions de Minuit.

BROMLEY R. (2006), “On and Off Campus : Colleges and Universities as Local Stakeholders”, Planning, Practice \& Research, 21, 1, pp. 1-24.

BYRAM M. (1991), “Biculturalisme : l'enfant et l'école”, in LEMAN J. (dir.), Integrité, intégration Innovation pédagogique et pluralité culturelle, Brussels, Editions Universitaires/De Boeck Université, pp. 131-172.

CASTLES S. \& MILLER M. J. (1998), The age of migration, New York, Guilford Press.

CHAMBON J-L., DAVID A. \& DEVEVEY J-M. (1982), Les innovations sociales, Paris, PUF.

CHARLES D. (2003), “Universities and Territorial Development : Reshaping the Regional Role of UK Universities”, Local Economy, 18, 1, pp. 7-20.

CHARLES D. et al. (coord.) (2007), City-Regions as Intelligent Territories: Inclusion, Competitiveness and Learning, (CRITICAL) Final Report, Newcastle, Newcastle University.

CLANET C. (ed.) (1985), L'interculturel en éducation et en sciences humaines, Toulouse, Presses Universitaires du Mirail.

CROPLEY A. (2001), Creativity in Education and Learning: A Guide for Teachers and Educators, London, Kogan.

CROWTHER D., CUMMINGS C., DYSON A. \& MILLWARD A. (2003), Schools and area regeneration, Bristol, The Policy Press in association with Joseph Rowntree Foundation.

CRUL M. (2008), “The Second Generation in Europe”, Canadian Diversity, Spring 2008, pp. 17-19. CUMMINGS C. \& DYSON A. (2007), “The role of schools in area regeneration”, Research Papers in Education, 22, 1, pp. 1-22.

DAVID P. \& FORAY D. (2002), "An introduction to the economy of the knowledge society", International Social Science Journal, 171, pp. 9-23. 
DAVIES L. (2006), “Global citizenship : abstraction or framework for action ?”, Educational Review, 58,1, pp. 5-25.

DEWEY J. (1997), Experience \& Education, New York, Touchtone.

ENGIN F. \& TURNER B. (Eds) (2002), Handbook of Citizenship Studies, London, Sage.

FERRÃO J. (1995), “Colectividades territoriais e globalização : contributos para uma nova acção estratégica de emancipação”, Inforgeo, 9-10, pp. 65-75.

FERRÃO J. (1996), “Educação, sociedade cognitiva e regiões inteligentes : uma articulação promissora”, Inforgeo, 11, pp. 97-104.

FLORIDA R. (2008), Who's your city ?: How the Creative Economy Is Making Where to Live the Most Important Decision of Your Life, New York, Basic Books.

FORREST R. \& KEARNS A. (2001), “Social Cohesion, Social Capital and the Neighbourhood”, Urban Studies, 38, 12, pp. 2125-2143.

FREIRE P. (1987), Pedagogia do Oprimido, Rio de Janeiro, Paz e Terra.

FRIEDMAN J. (1992), Empowerment : The Politics of Alternative Development, Cambridge (MA), Blackwell.

FURLANETTO A. \& OLIVEIRA M. (2005), Fatores estratégicos associados às práticas de gestão do conhecimento, Análise, 19, 1, pp. 99-123.

GARCÍA M. (2006), “Citizenship practices and urban governance in European cities”, Urban Studies , 43, 4, pp. 745-765.

GERTLER M. S. \& VINODRAI T. (2004), “Anchors of creativity : How do public universities create competitive and cohesive communities ?", presented at Building Excellence: Graduate Education and Research, a conference sponsored by the University of Toronto, $4^{\text {th }}$ December 2004.

GLASERSFELD E. (1995), Radical Constructivism : A Way of Knowing and Learning, London, Routledge.

GONZÁLEZ X. (2007), “Educación Geográfica y Ciudadanía”, Didáctica Geográfica, 3ª época, 9, pp. 11-32.

GORDON J. (2008), “Community responsive schools, mixed housing, and community Regeneration”, Journal of Education Policy, 23, 2, pp. 181-192.

GRADSTEIN M. \& JUSTMAN M. (2002), “Education, Social Cohesion, and Economic Growth", The American Economic Review, 92, 4, pp. 1192-1204.

GRAHAM S. (2002), “Bridging urban digital divides ?”, Urban Studies, 39, 1, pp. 33-56.

GREEN M. (1995), Releasing the Imagination : Essays on Education, the Arts, and Social Change, San Francisco, Jossey-Bass Publishers.

HEATER D. (2004), Citizenship : The Civic Ideal in World History, Politics and Education, $3^{\text {rd }}$ ed., Manchester, Manchester University Press.

HOFF B.V.D., VIJVERS J., RIDDER J. de (2003), “Foundations and applications of knowledge management scan", European Management Journal, 21, 2, pp. 237-246.

KALBERG S. (1993), “Cultural Foundations of Modern Citizenship”, in TURNER B. (Ed.), Citizenship and Social Theory, London, Sage, pp. 91-114.

KATZ J. \& RICE R. (2002), Social Consequences of Internet Use : Access, Involvement, and Interaction, Cambridge (MA), The MIT Press. 
KLEIN J.L. \& LAURIN S. (2005), "Citoyenneté active et conscience territorial : perspectives pour un programme", in KLEIN J.L. \& LAURIN S. (Dir.), L"éducation géographique : formation du citoyen et conscience territorial, $2^{\text {nd }}$ ed., Sainte-Foy (Québec), Presses de l"Université du Québec, pp. 237-242.

KOKOREFF M. (2003), La Force des Quartiers - de la délinquance à l'engagement politique, Paris, Payot.

LAMBOOY J. G. \& MOULAERT F. (1996), “The economic organization of cities : an institutional perspective”, International Journal of Urban and Regional Research, 20, 2, pp. 217-237.

LINDO F. (1995), "Ethnic myth or ethnic might? On the divergence in educational attainment between Portuguese and Turkish youths in the Netherlands", in BAUMANN G. \& SUNIER T. (Eds.), De-essentializing Post-migration ethnicity : cohesion, commitments, comparison, Amsterdam, IMESUniversity of Amsterdam, pp. 144-164.

MALHEIROS J. (2002), “Ethni-cities : Residential Patterns in Northern European and Mediterranean Metropolises - Implications for Policy Design", International Journal of Population Geography, 8, 2, pp. 107-134.

MAYHEW S. (Ed.) (2004), A Dictionary of Geography (Article : Governmentality), Oxford, Oxford University Press.

MITCHELL K. (2003), "Educating the national citizen in neoliberal times : from the multicultural self to the strategic cosmopolitan", Transactions of the Institute of British Geographers, 28, pp. 387-403.

MODOOD T. (2003), “Ethnic differentials in Educational performance”, in MASON D. (Ed.), Explaining Ethnic Differences : Changing Patterns of Disadvantage in Britain, Bristol, Policy Press, pp. 53-68.

MOUFFE C. (Ed.) (1992), Dimensions of Radical Democracy : Pluralism, Citizenship, Community, London, Verso.

MOULAERT F., MORLICCHIO E. \& CAVOLA L. (2007), "Social exclusion and urban policy in European cities : combining 'Northern' and 'Southern' European perspectives", in GEYER H. S. (Ed.), International Handbook of Urban Policy, Volume I : Global Issues, Cheltenham, Edward Elgar Publishing Co, pp. 138-158.

MOULAERT F., MARTINELI F., SWYNGDOUW E. \& GONZÁLEZ S. (2010), Can neighbourhoods save the city? Community Development and Social Innovation, London, Routledge.

MURIE A. \& MUSTERD S. (2004), "Social Exclusion and Opportunity Structures in European Cities and Neighbourhoods", Urban Studies, 41, 8, pp. 1441-1459.

NINACS W. (2008), Empowerment et intervention : Développement de la capacité d'agir et de la solidarité, Québec, Presses de l"Université du Québec.

NORRIS P. (2001), Digital Divide : Civic Engagement, Information Poverty, and the Internet Worldwide, Cambridge (UK), Cambridge University Press.

OECD (2009), Education at a Glance 2009 : OECD indicators, http://www.oecd.org/ dataoecd/41/25/43636332.pdf.

OSLER A. \& STARKEY H. (2003), "Learning for Cosmopolitan Citizenship : theoretical debates and young people's experiences”, Educational Review, 55, 3, pp. 243-254.

PEROTTI A. (1994), Plaidoyer pour l'Interculturel, Strasbourg, Les Editions du Conseil de l'Europe. PERRY D. C. \& WIEWEL W. (2005), The University as Urban Developer, Armonk, NY, M. E. Sharpe. 
PLUMB D., LEVERMAN A. \& MCGRAY R. (2007), “The learning city in a 'planet of slums”, Studies in Continuing Education, 29, 1, pp. 37-50.

PORTER D. \& CRAIG D. (2004), "The third way and the third world : poverty reduction and social inclusion in the rise of 'inclusive' liberalism", Review of International Political Economy, 11, 2, pp. 387-423.

POWELL W. \& SNELLMAN K. (2004), “The Knowledge economy”, Annual Review of Sociology, 30, pp. 199-220.

RAFONI B. (2003), "La recherche interculturel : état des lieux en France”, Questions de communication, 4, pp. 13-26.

REX J. (1985), "Equality of Opportunity and the Ethnic Minority Child in British Schools", in MODGIL S. et al. (ed.), Multi-Cultural Education - The Interminable Debate, London, Falmer Press, pp. 205-219.

ROBINSON C. \& ADAMS N. (2008), "Unlocking the Potential : The Role of Universities in Pursuing Regeneration and Promoting Sustainable Communities", Local Economy, 23, 4, pp. 277-289.

ROBINSON K. (Coord.) (1999), All Our Futures : Creativity, Culture and Education. Report to the United Kingdom Secretary of State for Education and Employment and the Secretary of State for Culture, Media and Sport. London, National Advisory Committee on Creative and Cultural Education.

ROBINSON K. (2001), Out of Our Minds : Learning to be Creative, Oxford, Capstone.

ROCHA-TRINDADE M. B. (1993), "Perspectivas Sociológicas da Interculturalidade”, Análise Social, 28, 123-124, pp. 869-878.

ROOSENS E. (1991), “Migration et interculturalisme”, in LEMAN J. (dir.), Integrité, intégration Innovation pédagogique et pluralité culturelle, Brussels, Editions Universitaires/De Boeck Université, pp. 17-46.

RURY J. (2002), Education and Social Change. Themes in the History of American Schooling, Mahwah, NJ, Lawrence Erlbaum Associates.

SANDERCOCK L (1998), Towards Cosmopolis, Chichester, Wiley.

SANTOS B. S. (2002), A crítica da razão indolente : Contra o desperdício da experiência, $2^{\text {nd }}$ Ed., Porto, Edições Afrontamento.

SELWYN N. (2008), "O uso das TIC na educação e a promoção de inclusão social : uma perspectiva crítica do Reino Unido”, Educação \& Sociedade, 29, 104, pp. 815-850.

SUTTON R. (1991), "Equity and Computers in the Schools : A Decade of Research", Review of Educational Research, 61, 4, pp. 475-503.

TIEROLF B. and NEDERLAND T. (2008), Exclusion and Inclusion in Education and Training (KATARSIS), Final Report, http://cordis.europa.eu/documents/documentlibrary/124376771EN6.pdf

WAITE L. (2012), "Neo-assimilationist citizenship and belonging policies in Britain : Meanings for transnational migrants in northern England", Geoforum, 43, 2, pp. 353-361.

WARSSCHAUER M. (2002), "Reconceptualizing the digital divide”, First Monday, http:// firstmonday.org/htbin/cgiwrap/bin/ojs/index.php/fm/article/viewArticle/967/888\#w6.

WHITTY G (2001), “Education, social class and social exclusion”, Journal of Education Policy, 16, 4, pp. 287-295. 
WILSON B. G. (Ed.) (1996), Constructivist Learning Environments : Case Studies in Instructional Design, New Jersey, Educational Technology Publications.

WOOLGAR S. (2002), Virtual society : technology, cyberbole reality, Oxford, Oxford University Press.

\section{NOTES}

1. In OECD countries, "top performers" form $10.0 \%$ of the first group and $5.6 \%$ of the second.

2. Roseens (1991, pp. 24-25) provides examples of this principle for Belgium and also mentions cases from the Netherlands and Canada.

3. Ricardo Mendez - Conference "Empleo y Economia del Conocimiento en la Region Metropolitana de Madrid", June 2011, Ciclo 22, Centre for Geographical Studies, University of Lisbon.

\section{ABSTRACTS}

Learning is a central factor of social and spatial cohesion. Educational institutions play a significant role in the reproduction or transformation of social relations by conveying values and practices that either sustain or contradict the dominant societal structures. Learning is also crucial for the enhancement of urban governance, insofar as it is associated with the promotion of critical thinking, access to information and participation in collective decision-making processes. This article discusses how education contributes to inclusive urban development and local collective identities through the responses it provides to three issues - innovation and creativity, citizenship, and cultural diversity - that have become crucial challenges to urban social cohesion. The last section aims to materialise this discussion around two concrete urban processes : the development of local learning communities - learning from the city ; and the role of educational institutions in socially inclusive urban regeneration processes - learning for the city.

L'apprentissage représente un facteur essentiel de cohésion socio-spatiale. Les institutions éducatives jouent un rôle déterminant dans la reproduction ou la transformation des rapports sociaux au sens où ils véhiculent des valeurs et des pratiques qui appuient les structures sociétales dominantes ou au contraire vont à leur encontre. L'apprentissage est également crucial pour l'amélioration de la gouvernance urbaine, dans la mesure où il est associé à la promotion de la pensée critique, de l'accès à l'information et de la participation aux processus collectifs de décision. Cet article analyse comment l'éducation contribue au développement urbain inclusif ainsi qu'aux identités locales collectives à travers les réponses apportées à trois questions: innovation et créativité, citoyenneté, diversité culturelle. Celles-ci sont devenues des défis majeurs pour la cohésion sociale dans les villes. La dernière section a pour but de concrétiser cette discussion autour de deux processus urbains significatifs : le développement de communautés locales d'apprentissage - apprendre de la ville; le rôle des institutions éducatives dans les processus de régénération urbaine socialement inclusifs - apprendre pour la ville. 


\section{INDEX}

Mots-clés: éducation, savoir, apprentissage, innovation sociale, cohésion sociale urbaine, communautés locales

Keywords: education, knowledge, learning, social innovation, urban social cohesion, local communities

\section{AUTHORS}

\section{ISABEL ANDRÉ}

CEG/IGOT-UL - Centre for Geographical Studies/Institute of Geography and Spatial Planning, University of Lisbon, isabelandre@campus.ul.pt

\section{ANDRÉ CARMO}

CEG/IGOT-UL - Centre for Geographical Studies/Institute of Geography and Spatial Planning, University of Lisbon, carmo@campus.ul.pt

\section{ALEXANDRE ABREU}

CEG/IGOT-UL - Centre for Geographical Studies/Institute of Geography and Spatial Planning, University of Lisbon, alexabreu@gmail.com

\section{ANA ESTEVENS}

CEG/IGOT-UL - Centre for Geographical Studies/Institute of Geography and Spatial Planning, University of Lisbon, anaestevens@gmail.com

\section{JORGE MALHEIROS}

CEG/IGOT-UL - Centre for Geographical Studies/Institute of Geography and Spatial Planning, University of Lisbon, jmalheiros@campus.ul.pt 